\title{
ACCESSIBILITY EVALUATION OF THE TRANSIT PLAZA OF TANAH ABANG STATION ACCORDING TO USERS WITH VISUAL IMPAIRMENT
}

\author{
${ }^{1}$ Tamara Bonita, ${ }^{2}$ Aldyfra L. Lukman, Ph. D \\ ${ }^{1}$ Student in the Bachelor's (S-1) Study Program in Architecture \\ at Parahyangan Catholic University \\ 2 Senior lecturer in the Bachelor's (S-1) Study Program in Architecture \\ at Parahyangan Catholic University
}

\begin{abstract}
Visual impairment is a term given to someone who does not have healthy vision. To fulfill their daily life needs, people with visual impairment tend to depend on the facilities in public open spaces. Accessibility that should support people with visual impairment in using public transportation facilities is often poorly maintained. This kind of condition could lead to fatal consequences to the safety of persons with disabilities. Options linked to accessing public open spaces for people with visual impairment become limited due to the lack of facilities. The refurbishment has been done at Tanah Abang Station by providing a transit plaza for users that is connected to various public transportation facilities, which enables easy and comfortable navigation. This has become an opportunity, to build better public facilities that are accessible to all users, including for people with visual impairment. Through this effort, the transit plaza should be able to serve as a public space that is beneficial for people with visual impairment, so there are more possibilities to ensure their quality of life. The purpose of this study is to determine the extent to which the transit plaza can provide accessibility for people with visual impairment. The method used is qualitative and data collection was carried out through literature studies, field surveys as well as interviews and simulations with people with visual impairment. The results conclude that the accessibility value referring to technical requirements indicates that the transit plaza sufficiently complies with accessibility standards regarding public open spaces. This value is compared to the experience of people with visual impairment. This study found that there are some differences from the aspect of convenience according to the people with visual impairment's point of view. The mobility in the transit plaza is considered easy and safe by people with visual impairment. When they had to determine direction or orientation, people with visual impairment who were not familiar with transit plaza still had difficulties to navigate independently. When facing these situations, blind people adapted by relying on abilities other than their sight as an alternative. Transit plaza could provide universal convenience for users by accommodate accessibility that can not only encourage the independence of the people with visual impairment, but also support comfort and safety of individuals without visual impairment.
\end{abstract}

Keywords: Visual impairment, accessibility, transit plaza

\section{EVALUASI AKSESIBILITAS BAGI TUNANETRA DI PLAZA TRANSIT STASIUN TANAH ABANG}

\author{
${ }^{1}$ Tamara Bonita, ${ }^{2}$ Aldyfra L. Lukman, Ph. D \\ ${ }^{1}$ Mahasiswi S1 Program Studi Arsitektur Universitas Katolik Parahyangan \\ ${ }^{2}$ Dosen Pembimbing S1 Program Studi Arsitektur Universitas Katolik Parahyangan
}

\begin{abstract}
Abstrak - Tunanetra merupakan istilah yang diberikan pada seseorang dengan kondisi penglihatan kurang atau tidak baik. Tuntutan untuk memenuhi kebutuhan hidup membawa tunanetra untuk turut bergantung pada ketersediaan fasilitas di ruang terbuka publik. Khususnya dalam memanfaatkan transportasi umum, aksesibilitas bagi tunanetra sering kali tidak lengkap atau tidak terawat. Tidak tersedianya kemudahan menyebabkan pilihan
\end{abstract}

${ }^{1}$ Corresponding Author: 4215039@student.unpar.ac.id 
untuk mengakses ruang terbuka publik bagi tunanetra menjadi terbatas. Adanya renovasi yang dilakukan di Stasiun Tanah Abang dalam bentuk penyediaan plaza transit, menjadi peluang untuk menciptakan fasilitas publik yang aksesibel bagi semua kalangan penggunanya termasuk kaum tunanetra. Penataan dilakukan untuk memberi kemudahan bagi penggunanya agar dapat terkoneksi dengan berbagai pilihan moda transportasi dengan mudah dan nyaman. Melalui usaha penataan ini, plaza transit dapat menjadi ruang publik yang juga bermanfaat bagi kaum tunanetra, sehingga dapat membuka kesempatan bagi tunanetra untuk menjamin kualitas hidupnya. Tujuan dari penelitian adalah untuk mengetahui sejauh mana plaza transit tersebut dapat mendukung aksesibilitas bagi tunanetra. Metode yang digunakan bersifat kualitatif dan pengumpulan data dilakukan melalui studi literatur, survey lapangan serta wawancara dan simulasi bersama narasumber tunanetra. Kesimpulan nilai aksesibilitas berdasarkan persyaratan teknis menyatakan bahwa plaza transit cukup baik memenuhi standar aksesibilitas di ruang terbuka publik. Nilai tersebut dibandingkan dengan pengalaman tunanetra dan ditemukan adanya beberapa perbedaan dari aspek kemudahan menurut sudut pandang tunanetra. Kemudahan dalam melakukan mobilitas di plaza transit, dirasa cukup mudah dan aman bagi tunanetra. Untuk menentukan arah atau orientasi, tunanetra yang belum familiar dengan plaza transit masih menemukan kesulitan dan belum bisa melakukannya secara mandiri. Dalam menghadapi kesulitan yang ada, tunanetra beradaptasi dengan mengandalkan kemampuan diluar penglihatan sebagai alternatif. Plaza transit dapat memberikan kemudahan penggunanya secara universal dengan menyediakan aksesibilitas yang tidak hanya dapat mendorong kemandirian tunanetra, namun juga mendukung kenyamanan dan keamanan bagi semua orang.

Kata-kata kunci: Tunanetra, aksesibilitas, plaza transit

\section{PENDAHULUAN}

Keadaan penyandang disabilitas di Indonesia yang turut menjadi kaum minoritas yang termarginalisasi di dalam kehidupan bermasyarakat, tercerminkan dari penyediaan fasilitas umum yang cenderung menyamaratakan kemampuan seseorang dalam pemanfaatan sarana dan prasarana. Kondisi ini memberikan hambatan bagi penyandang disabilitas dalam memanfaatkan ruang terbuka publik khususnya bagi tunanetra. Dalam kehidupan kota, moda transportasi umum menjadi fasilitas yang sangat diandalkan untuk memberikan kesempatan bagi semua orang mencapai lokasi yang dibutuhkan. Berbagi ruang dengan transportasi umum tidaklah sederhana bagi kaum tunanetra. Aksesibilitas yang tidak menunjang kondisi tunanetra, dapat membawa mereka ke dalam situasi berbahaya. Jumlah tunanetra di Indonesia sendiri memiliki angka yang tidak sedikit. Namun demikian, jarang ditemukan kehadiran aktivitas tunanetra pada area-area terbuka dan fasilitas umum.

Perkembangan moda transportasi saat ini menyediakan ragam alternatif pilihan demi menunjang mobilitas masyarakat dalam kehidupan kota. Mulai dari bajaj, angkot, kopaja, transjakarta, taxi online, ojek online, KRL (Commuter Line) hingga MRT (Mass Rapid Transit) dan LRT (Light Rail Transit) menjadi pilihan transportasi umum di Jakarta. Pemprov DKI Jakarta berusaha melakukan penataan untuk mewujudkan integrasi antar transportasi melalui penyediaan stasiun terpadu yang dilakukan pada kawasan Stasiun KRL sebagai satu dari tiga tulang punggung transportasi massal. Kawasan Stasiun Tanah Abang merupakan salah satu fasilitas yang telah selesai direnovasi, dengan menyediakan plaza transit yang akan menghubungkan penumpang dari stasiun menuju moda transportasi umum lain seperti gojek, bajaj, angkutan umum, dan transjakarta. Plaza transit ini ditempatkan pada sisi pintu utara Stasiun Tanah Abang yang terhubung dengan Jalan Jatibaru Raya. Penelitian ini akan meninjau plaza transit di Stasiun Tanah Abang, untuk menilai sejauh mana aksesibilitas ruang terbuka publik telah memperhatikan kebutuhan tunanetra sehingga fasilitas dapat berfungsi secara universal. Aksesibilitas menuju transportasi umum yang baik dibutuhkan agar dapat membuka kesempatan bagi tunanetra untuk meningkatkan kualitas hidup yang lebih baik.

Rumusan masalah yang diangkat adalah mengenai pemanfaatan ruang terbuka publik dalam pencapaian menuju transportasi umum bagi tunanetra. Penataan yang telah selesai dilaksanakan pada Plaza Transit Stasiun Tanah Abang menjadi kesempatan untuk memberikan 
pelayanan transportasi yang aksesibel bagi semua orang termasuk penyandang disabilitas seperti tunanetra. Melalui fenomena yang ada maka penelitian ini dilakukan untuk mengukur sejauh mana elemen-elemen fisik di Plaza Transit Stasiun Tanah Abang mengakomodasi aksesibilitas pengunjung tunanetra. Tujuan penelitian adalah untuk memahami kebutuhan orientasi dan mobilitas tunanetra dan untuk mengidentifikasi elemen-elemen aksesibilitas di Plaza Transit Stasiun Tanah Abang yang mana saja yang perlu memperoleh perhatian khusus. Manfaat dilakukannya penelitian agar dapat dijadikan wawasan serta membangun awareness akan kebutuhan kaum tunanetra yang memiliki perbedaan kemampuan dalam menjalani aktivitasnya.

\section{KAJIAN TEORI}

\subsection{DESAIN UNIVERSAL DAN AKSESIBILITAS}

Desain universal adalah cara merancang fasilitas, dengan sedikit atau tanpa biaya tambahan, sehingga menarik dan fungsional untuk semua orang, baik cacat atau tidak ${ }^{2}$. Desain universal memiliki dasar pendekatan dari konsep desain bebas hambatan (barrier-free design) dan desain yang aksesibel (accessible design). Hambatan sendiri dapat ditemui pada berbagai aktivitas keseharian manusia seperti misalnya, hambatan dalam bergerak, hambatan dalam ruang dan waktu, hambatan akses, hambatan komunikasi, ataupun hambatan dalam persepsi dan berekspresi. Hambatan tertentu dapat menyulitkan bagi suatu kelompok tetapi bisa juga tidak bermasalah bagi kelompok lain. Melalui Peraturan Menteri PUPR Nomor 14/PRT/M/2017 tentang Persyaratan Kemudahan Bangunan Gedung, aksesibilitas adalah kemudahan yang disediakan bagi semua orang guna mewujudkan kesamaan kesempatan dalam segala aspek kehidupan dan penghidupannya. Dari pengertian yang ada, desain universal memiliki peran untuk menciptakan aksesibilitas yang baik bagi semua penggunanya.

\subsection{PENGERTIAN TUNANETRA}

Tunanetra di Indonesia secara umum dipahami sebagai istilah yang digunakan untuk kondisi seseorang yang mengalami gangguan penglihatan atau singkatnya kebutaan. Dalam Kamus Bebas Bahasa Indonesia kata "tuna" mengandung arti rusak, cacat, sedangkan "netra" berarti mata. Definisi legal terkait gangguan penglihatan adalah keadaan ketajaman visual yang tidak lebih dari 3/60 dengan sudah menggunakan koreksi dan bidang penglihatan kurang dari 20 derajat. Maksudnya adalah jika seseorang tanpa gangguan penglihatan dapat melihat suatu objek sejauh 60 meter, maka bagi orang dengan kebutaan baru dapat melihat objek tersebut dengan ketajaman yang sama, dengan jarak 3 meter.
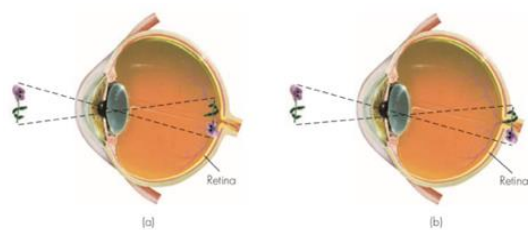

Gambar 1. Jatuhnya Cahaya Pada Miopi dan Hipermetropi

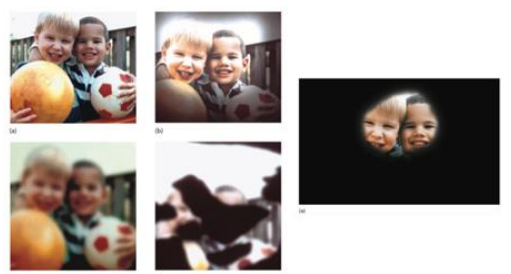

Gambar 2. Gangguan Penglihatan Dalam Kebutaan

\footnotetext{
${ }^{2}$ Mace, Ronald. (1991). Accessible Environments: Toward Universal Design. USA: The Center for Universal Design North Carolina State University
} 
Tabel 1. Range of Reading Ability Sumber : Visual Standart by Colenbrander

\begin{tabular}{|c|c|c|c|}
\hline \multirow{2}{*}{$\begin{array}{c}\text { Ranges } \\
\text { of Vision } \\
\text { Loss }\end{array}$} & \multicolumn{3}{|c|}{$\begin{array}{l}\text { Visual Acuity } \\
\text { (how the eye functions) }\end{array}$} \\
\hline & $\begin{array}{c}\text { Decimal } \\
\text { notation }\end{array}$ & $\begin{array}{l}\text { Letter } \\
\text { count }\end{array}$ & $\begin{array}{l}\text { Reads } \\
1 \mathrm{M} \text { at: }\end{array}$ \\
\hline $\begin{array}{l}\text { Range of } \\
\text { Nomal } \\
\text { Vision }\end{array}$ & $\begin{array}{l}1.6 \\
1.25 \\
1.0 \\
0.8 \\
\end{array}$ & $\begin{array}{c}110 \\
105 \\
100 \\
95 \\
\end{array}$ & $\begin{array}{l}160 \mathrm{~cm} \\
125 \mathrm{~cm} \\
100 \mathrm{~cm} \\
80 \mathrm{~cm}\end{array}$ \\
\hline $\begin{array}{l}\text { Minimal } \\
\text { Impairment }\end{array}$ & $\begin{array}{l}0.63 \\
0.5\end{array}$ & $\begin{array}{l}90 \\
85\end{array}$ & $\begin{array}{l}63 \mathrm{~cm} \\
50 \mathrm{~cm}\end{array}$ \\
\hline $\begin{array}{l}\text { Mild } \\
\text { Impairment }\end{array}$ & $\begin{array}{l}0.4 \\
0.32 \\
\end{array}$ & $\begin{array}{l}80 \\
75 \\
\end{array}$ & $\begin{array}{l}40 \mathrm{~cm} \\
32 \mathrm{~cm} \\
\end{array}$ \\
\hline $\begin{array}{l}\text { Moderate } \\
\text { Visual } \\
\text { Impairment }\end{array}$ & $\begin{array}{l}0.25 \\
0.2 \\
0.16 \\
0.125 \\
\end{array}$ & $\begin{array}{l}70 \\
65 \\
60 \\
55 \\
\end{array}$ & $\begin{array}{l}25 \mathrm{~cm} \\
20 \mathrm{~cm} \\
16 \mathrm{~cm} \\
12.5 \mathrm{~cm}\end{array}$ \\
\hline $\begin{array}{l}\text { Severe } \\
\text { Visual } \\
\text { Impairment }\end{array}$ & $\begin{array}{l}0.1 \\
0.08 \\
0.063 \\
0.05 \\
\end{array}$ & $\begin{array}{l}\mathbf{5 0} \\
45 \\
40 \\
35\end{array}$ & $\begin{array}{c}10 \mathrm{~cm} \\
8 \mathrm{~cm} \\
6.3 \mathrm{~cm} \\
5 \mathrm{~cm}\end{array}$ \\
\hline $\begin{array}{l}\text { Profound } \\
\text { Visual } \\
\text { Impairment }\end{array}$ & $\begin{array}{l}0.04 \\
0.032 \\
0.025 \\
0.02 \\
\end{array}$ & $\begin{array}{l}30 \\
25 \\
20 \\
15 \\
\end{array}$ & $\begin{array}{c}4 \mathrm{~cm} \\
3.2 \mathrm{~cm} \\
2.5 \mathrm{~cm} \\
2 \mathrm{~cm}\end{array}$ \\
\hline $\begin{array}{l}\text { Near- } \\
\text { Blindness }\end{array}$ & Less & $\begin{array}{c}10 \\
5 \\
0\end{array}$ & Less \\
\hline
\end{tabular}

\begin{tabular}{|c|c|l|}
\hline \multicolumn{3}{|c|}{$\begin{array}{c}\text { Statistical estimates of Reading Ability } \\
\text { (how the person functions) }\end{array}$} \\
\hline $\begin{array}{c}\text { Ability } \\
\text { Ranges }\end{array}$ & Reading Ability & \multicolumn{1}{|c|}{ Comments } \\
\hline $\begin{array}{c}\text { Has } \\
\text { reserves } \\
(100 \pm 10)\end{array}$ & $\begin{array}{c}\text { Normal reading speed } \\
\text { Normal reading distance } \\
\text { Reserve capacity for } \\
\text { small print }\end{array}$ & $\begin{array}{l}\text { Since newsprint is generally read at } \\
\text { around 40 cm, this range has an } \\
\text { ample reserve. }\end{array}$ \\
\hline $\begin{array}{c}\text { Lost } \\
\text { reserves } \\
(80 \pm 10)\end{array}$ & $\begin{array}{c}\text { Normal reading speed } \\
\text { Reduced reading distance } \\
\text { No reserve for small print }\end{array}$ & $\begin{array}{l}\text { Individuals in this range have lost } \\
\text { their reserve, but have no or only } \\
\text { minimal vision rehabilitation needs. } \\
\text { (Driver's license and other criteria } \\
\text { usually fall within this range.) }\end{array}$ \\
\hline $\begin{array}{c}\text { Normal with } \\
\text { aids }\end{array}$ & $\begin{array}{c}\text { Near-normal with } \\
\text { appropriate reading aids } \\
(60 \pm 10)\end{array}$ & $\begin{array}{l}\text { Reading at 25...12.5 cm requires } \\
\text { and large print books } \\
\text { strong reading glasses (4D to } 8 \mathrm{D}) \text { or } \\
\text { moderate power magnifiers. } \\
\text { (In the U.S. students qualify for } \\
\text { special education assistance.) }\end{array}$ \\
\hline $\begin{array}{c}\text { Restricted } \\
\text { with aids } \\
(40 \pm 10)\end{array}$ & $\begin{array}{c}\text { Slower than normal } \\
\text { with reading aids } \\
\text { High power magnifiers } \\
\text { (restricted field) }\end{array}$ & $\begin{array}{l}\text { Reading at < 10 cm precludes } \\
\text { binocular vision. The small field of } \\
\text { strong magnifiers slows reading. } \\
\text { Vision substitution skills may be an } \\
\text { adjunct to enhancement aids. }\end{array}$ \\
\hline $\begin{array}{c}\text { Marginal } \\
\text { with aids } \\
(20 \pm 10)\end{array}$ & $\begin{array}{c}\text { Visual reading is limited } \\
\text { Uses magnifiers for spot } \\
\text { reading, but may prefer } \\
\text { talking books for leisure }\end{array}$ & $\begin{array}{l}\text { No visual reading } \\
\text { Use of non-visual skills increases as } \\
\text { rehabilitation needs shift gradually } \\
\text { from vision enhancement aids to } \\
\text { vision substitution aids. }\end{array}$ \\
$\begin{array}{c}\text { Must rely on talking books, } \\
\text { sources }\end{array}$ & $\begin{array}{l}\text { In this range individuals must rely } \\
\text { primarily on vision substitution skills. } \\
\text { Any residual vision becomes an } \\
\text { adjunct to the use of blind skills. }\end{array}$ \\
\hline
\end{tabular}

Bagi tunanetra, kemampuan orientasi dan mobilitas sangatlah penting untuk dapat menyesuaikan diri dengan baik. Orientasi dan mobilitas (O\&M) adalah kemampuan untuk merasakan di mana seseorang berada dalam hubungannya dengan orang lain, benda, orientasi, dan untuk bergerak pada suatu lingkungan (Hallahan, 2009). Melalui indera penglihatan, seseorang mampu menyusun pemahaman yang jelas dari lingkungan fisiknya tanpa perlu berusaha mengingat kembali. Tunanetra tidak memiliki kemampuan serupa sehingga membutuhkan metode khusus untuk mengenali lingkungan fisiknya. Tunanetra mengandalkan berbagai kemampuan sensorinya untuk mengumpulkan informasi yang diperlukan sebelum bisa mengenali suatu bentuk sebagai satu. Teknik dalam orientasi dan mobilitas bagi tunanetra sendiri ada beberapa cara yaitu :

- Guided travel, yaitu pergerakan dengan didampingi oleh orang lain sebagai pemandu jalan.

- Protective techniques, yaitu teknik meraba dengan tangan untuk menyentuh, merasakan dan mengidentifikasi rintangan yang ada.

- Mobility device, yaitu teknik dengan bantuan alat seperti tongkat pemandu.

- Dog guides, teknik dengan bantuan dari hewan yang telah dilatih secara khusus sebagai pemandu.

- Electronic travel aids, peralatan bergerak seperti kursi roda elektrik.

\subsection{PENGERTIAN RUANG TERBUKA PUBLIK}

Ruang terbuka dapat didefinisikan sebagai daratan dan air pada area kota/ urban yang tidak tertutupi oleh mobil ataupun bangunan (Gold, 1980). Dalam pernyataan lainnya, Tankel 
(1963) menyebutkan bahwa ruang terbuka tidak hanya sebatas daratan, atau air yang ada di area urban tetapi juga termasuk ruang dan cahaya yang ada pada lahan tersebut. Definisi terkait pemanfaatan ruang terbuka dapat dikategorikan menjadi publik, semi-publik, semi-privat dan privat (Newman, 1972) ${ }^{3}$. Ruang publik, dideskripsikan oleh Walzer (1986) merupakan tempat untuk berbagi ruang dengan orang lain, asing, orang-orang yang tidak memiliki hubungan sebagai keluarga, rekan atau teman. Ruang publik memiliki karakter yang mengekspresikan kondisi kehidupan, kultur, dan percakapan keseharian suatu lingkungan. Mengacu pada pemahaman yang ada maka, ruang terbuka publik merupakan area pada suatu kehidupan kota yang digunakan oleh berbagai kelompok individu maupun komunal dimana semua orang diperlakukan secara setara dalam menjalani aktivitasnya.

Pergerakan pemanfaatan pada ruang terbuka publik terbagi menjadi :

- Berjalan (Walking), sebagai bentuk transportasi yang dilakukan untuk berlalu lalang tanpa kerumitan untuk dapat hadir di lingkungan publik, termasuk pada gerakan berjalan yang menggunakan bantuan alat beroda seperti kursi roda atau kereta bayi.

- Berdiri (Standing), sebagai bentuk aktivitas berdiam yang dilakukan pada ruang terbuka publik. Berhenti dapat dilakukan pada titik-titik khusus yang disediakan pada ruang terbuka publik seperti di trotoar/ tepi jalan, dan fasad jalan. Kondisi berdiri dapat ditunjang denga adanya sarana untuk bersandar.

- Duduk (Sitting), sebagai bentuk aktivitas berhenti yang dilakukan dalam durasi waktu yang bebas (lebih lama). Umumnya melibatkan aktivitas beragam yang menarik untuk mengundang publik ke ruang terbuka seperti makan, membaca, tidur, bermain dan lainnya.

\subsection{PENGERTIAN TRANSPORTASI UMUM}

Transportasi adalah kegiatan pemindahan barang dan penumpang dari suatu tempat ke tempat lain. Dalam transportasi ada dua unsur yang terpenting yaitu pemindahan/pergerakan (movement) dan secara fisik mengubah tempat dari barang dan penumpang ke tempat lain ${ }^{4}$. Melalui pemahaman yang ada, transportasi dapat diartikan sebagai sebuah aktivitas memindahkan atau membawa benda dari satu tempat ke tempat lain. Sementara itu pada pengertian transportasi umum, kata "umum" mengacu pada orang banyak, semua orang, umum. Sehingga transportasi umum memiliki arti sebagai sebuah aktivitas berpindah yang diperuntukan atau dilakukan oleh orang banyak atau diperuntukkan secara publik. Peran transportasi umum sangat penting dalam perkembangan suatu wilayah. Meskipun demikian pengembangan sistem transportasi umum yang tidak tertata dapat memberikan dampak negatif seperti menimbulkan kepadatan, kecelakaan, dan ketidakteraturan.

\section{METODE PENELITIAN}

Penelitian dilakukan secara kualitatif dengan menganalisis elemen-elemen aksesibilitas dan kesesuaiannya terhadap pedoman teknis juga kenyamanannya bagi tunanetra sendiri.

\footnotetext{
${ }^{3}$ Woolley, H. (2003). Urban Open Space. London : Spon Press

${ }^{44}$ Andriansyah.(2015).Manajemen Transportasi Dalam Kajian Teori. Indonesia: Universitas Prof.Dr.Moestopo Beragama
} 
4. ANALISIS

4.1 DATA OBJEK

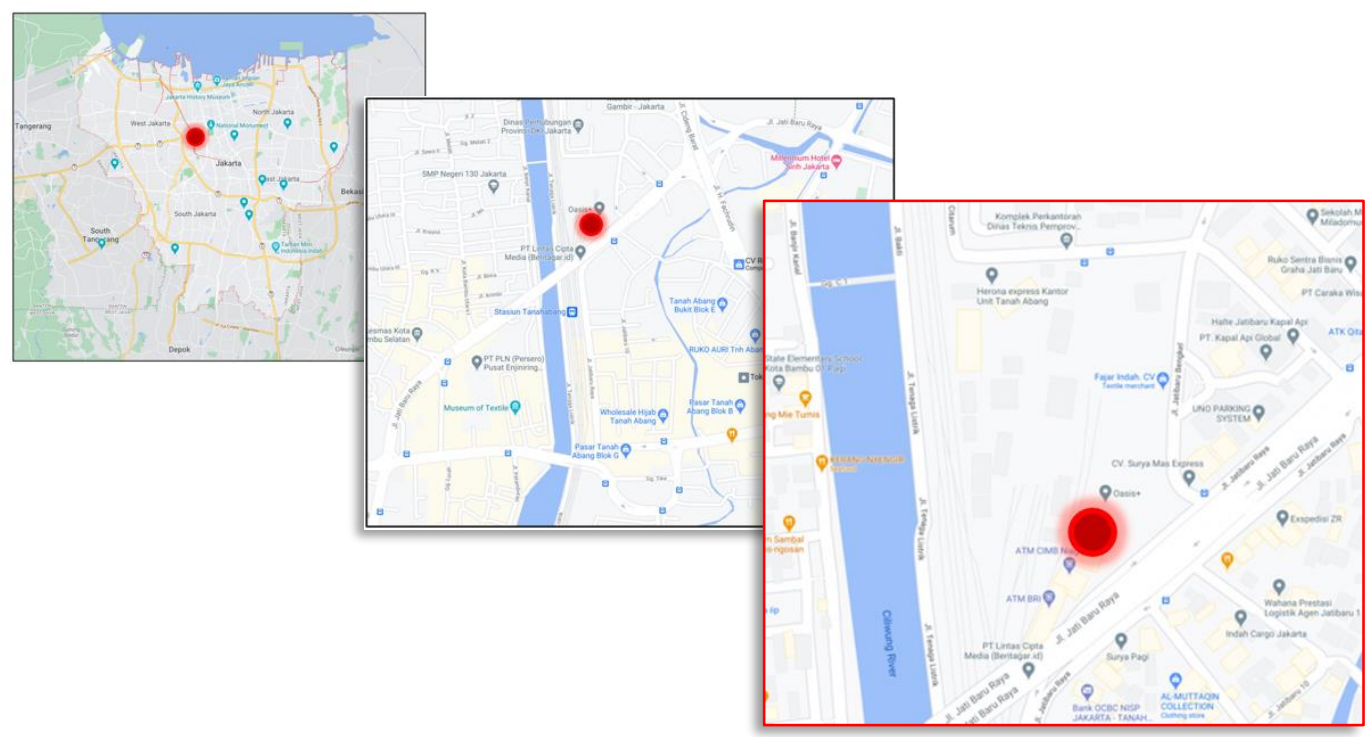

Gambar 3. Lokasi Plaza Transit Dilihat Dari Kota Jakarta, Kawasan Tanah Abang, Stasiun Tanah Abang

Sumber : googlemaps.com

Plaza Transit Stasiun Tanah Abang berlokasi di Jalan Jatibaru Raya, Cideng Timur, kecamatan Tanah Abang. Tanah Abang merupakan suatu kawasan di Jakarta yang dikenal sebagai salah satu pusat perbelanjaan grosir terbesar di Jakarta. Stasiun Tanah Abang sendiri telah berdiri sejak 1899 dan hingga saat ini selalu ramai akan pengunjung. Dibuatnya plaza transit di kawasan Stasiun Tanah Abang adalah untuk menampung mobilitas pengunjung Tanah Abang yang kian ramai khususnya pengunjung yang menggunakan moda kereta api sebagai sarana transportasi baik yang menuju maupun yang dari Tanah Abang.

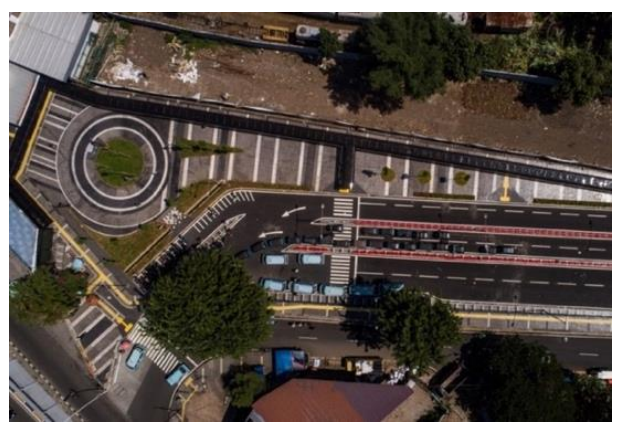

Gambar 4. Plaza Transit

Sumber : googleimage.com

Berdasarkan Rencana Tata Ruang Wilayah Jakarta Tahun 2030 kecamatan Kampung Bali - Tanah Abang menjadi bagian wilayah Kota Jakarta Pusat yang sedang dikembangkan dan menjadi pusat kegiatan perekonomian mulai dari perdagangan, jasa dan perkantoran. Demi mendukung rencana tersebut Stasiun Tanah Abang mengalami pengembangan dengan mengacu pada sistem TOD (Transit Oriented Development), yang kemudian menjadikan Stasiun Tanah Abang sebagai stasiun terpadu. Tujuannya adalah melakukan penataan untuk mewujudkan keteraturan guna menciptakan integrasi antarmoda publik yang ada sehingga 
dapat meminimalisir kemacetan dan ketidakteraturan. Integrasi moda transportasi umum sendiri merupakan upaya dalam manajemen sistem transportasi umum yang mengkombinasikan dua atau lebih moda transportasi umum untuk memberikan pelayanan publik yang optimal.

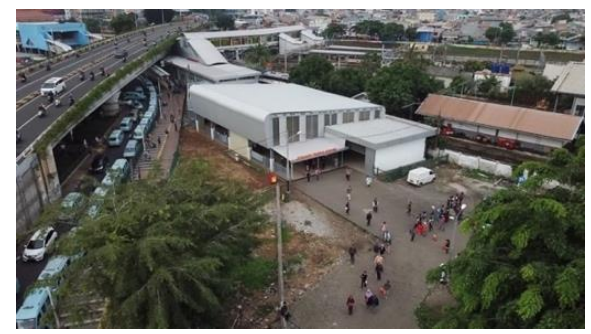

Gambar 5. Pintu Utara Satsiun Tanah Abang Sebelum Penataan Sumber : googleimage.com

Sebelum dilakukan penataan, area terbuka di sisi pintu utara stasiun merupakan lahan kosong. Lahan ini tidak memberikan akses yang jelas baik bagi pengunjung maupun transportasi umum yang ada. Akibatnya terjadi ketidakteraturan oleh pengguna ruang karena tidak adanya batasan dan pembagian area yang jelas.

Adanya plaza transit ditujukan untuk mengatur pergerakan pejalan kaki dari Stasiun Tanah Abang agar dapat mencapai transportasi umum dan melanjutkan perjalannya dengan mudah. Pelebaran trotoar menjadikan ruang terbuka publik pada plaza transit menjadi luas dan memaksimalkan perannya sebagai ruang perantara antara area stasiun dengan lingkungan sekitarnya. Aktivitas berpindah transportasi menunjukkan bahwa plaza transit menjadi ruang publik yang digunakan secara sementara oleh penggunanya. Dalam pemanfaatan ruang publik Gehl (2011) menyatakan terdapat pergerakan dasar berupa berjalan, berdiri, dan duduk. Pemanfaatan ruang publik yang ada pada plaza transit terdapat pada aktivitas berjalan untuk menuju pilihan moda transportasi yang ada, dan berdiri untuk menunggu diangkut oleh moda transportasi tersebut. Jangkauan pelayanan yang diwadahi mencakupi penumpang kereta api yang berasal dari Stasiun Tanah Abang dan juga penumpang yang datang dari lingkungan sekitar Tanah Abang menuju Stasiun Tanah Abang.

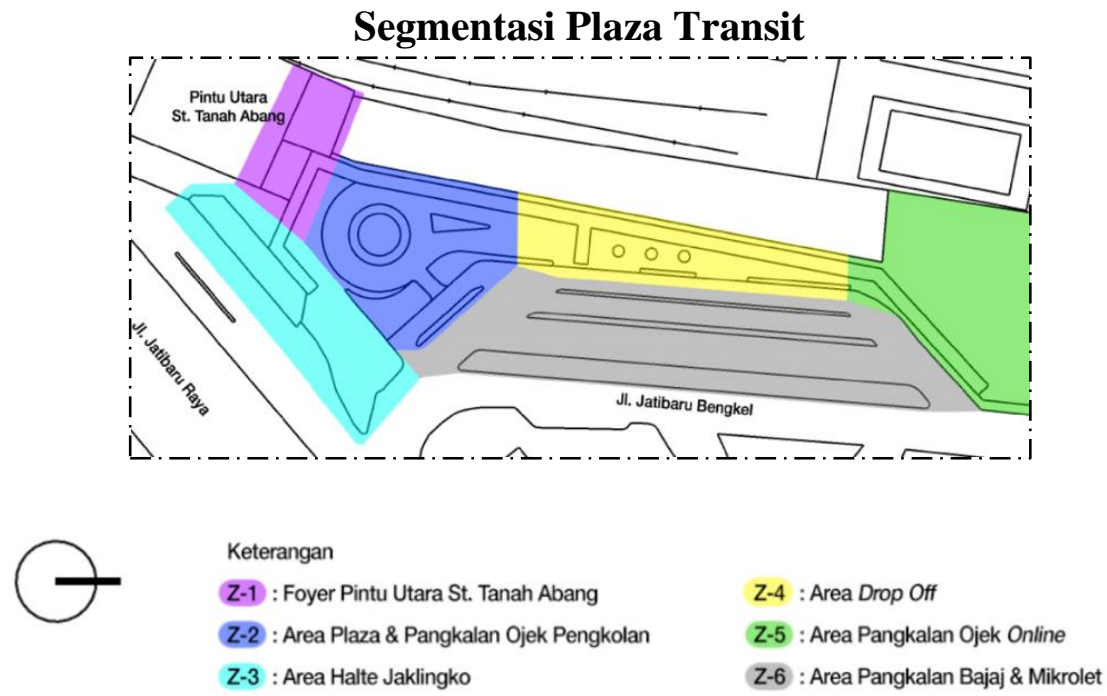

Gambar 6. Segmentasi Area Plaza Transit St. Tanah Abang 


\section{Sirkulasi Pejalan Kaki \& Kendaraan}

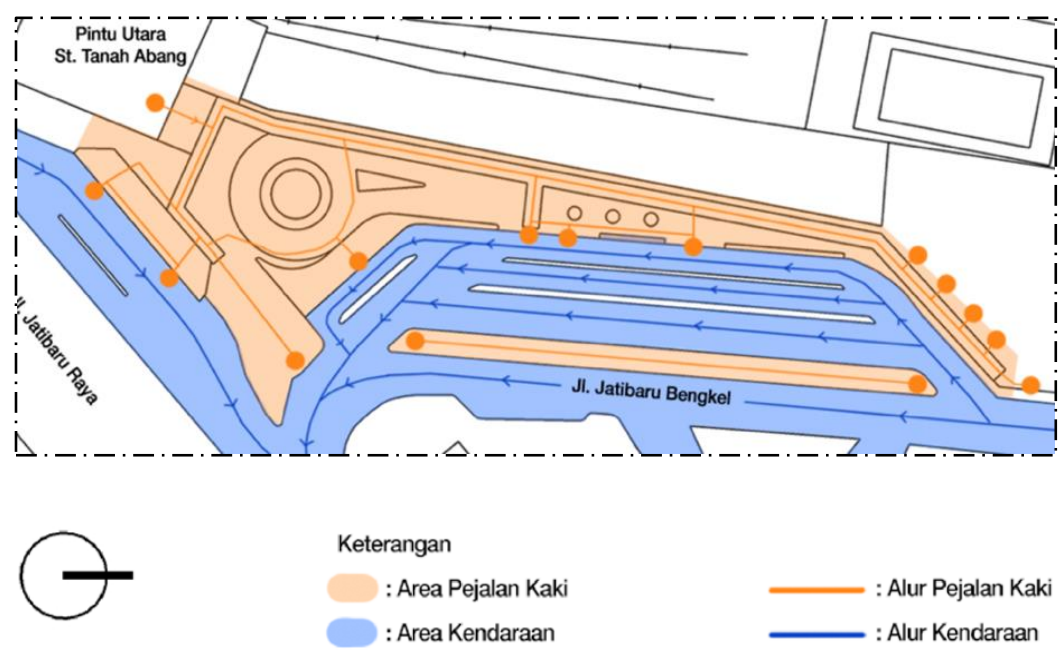

Gambar 7. Segmen Sirkulasi Plaza Transit St. Tanah Abang

Berikut ini moda transportasi yang tersedia di plaza transit:

1. Transjakarta

2. Ojek pengkolan (ojek konvensional)

3. Bajaj

4. Mikrolet

5. Taxi dan jemputan online

6. Ojek online

Plaza transit dibagi ke dalam 6 (enam) segmentasi berdasarkan area-area berangkat moda transportasi dan perbedaan fungsi ruang yang ada. Pembagian segmentasi tersebut yaitu segmen pintu utara, segmen plaza, segmen halte Jaklingko, segmen penyeberangan, segmen ojek pengkolan, segmen area drop-off, segmen pangkalan ojek online, dan segmen pangkalan bajaj \&mikrolet.
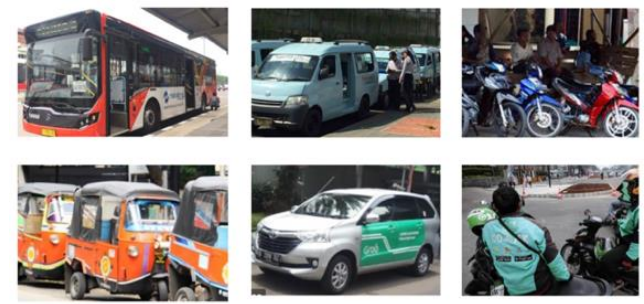

Gambar 8. Ragam Moda Transportasi di Plaza Transit Stasiun Tanah Abang Sumber : googleimage.com

Area pejalan kaki berada di trotoar yang dilebarkan dan menjadi ruang sirkulasi lalu lalang pejalan kaki yang ditandai dengan warna orange. Lalu plaza transit sebagai fasilitas penunjang dalam perpindahan moda transportasi memiliki area-area yang difokuskan juga untuk transit bagi kendaraan yang ditandai dengan warna biru. Arah laju transportasi dari sisi selatan plaza berasal dari Jl. Jatibaru Bengkel menuju ke Jl. Jatibaru Raya. Lalu moda transportasi ojek online masuk dari sisi Timur plaza yaitu melalui Jl. Jatibaru Taman yang 
terhubung dengan Jl. Citarum. Transjakarta datang dari arah Utara Jl. Jatibaru Raya melakukan pengangkutan penumpang pada halte Jaklingko yang berdekatan dengan pintu utara.

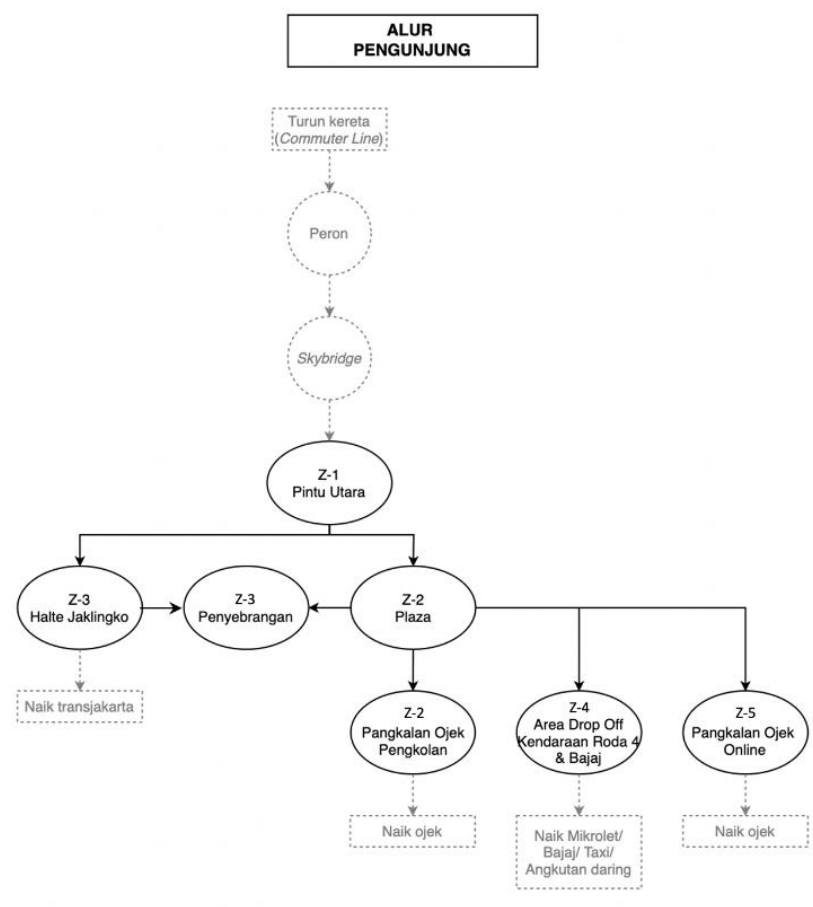

Gambar 9. Alur Pengunjung di Plaza Transit

Sebelum sampai di pintu utara Stasiun Tanah Abang, pengunjung yang berasal dari kereta api (Commuter Line) sampai di peron, lalu menyeberang melalui JPO (skybridge) untuk sampai di pintu utara stasiun. Setelah keluar dari akses pintu utara stasiun, telah disiapkan jalur khusus pejalan kaki menuju halte bus transjakarta, jalur menuju ojek pangkalan, mikrotrans, bajaj, ojek online, dan area drop-off. Alur pengunjung diawali ketika keluar dari akses utara Stasiun Tanah Abang, dimana akses pintu dari stasiun menuju plaza transit hanya melalui pintu utara ini. Kemudian mengikuti jalur yang disediakan, pengunjung akan berakhir di beberapa segmen berbeda, sesuai dengan pilihan moda transportasi umum yang dibutuhkan

\subsection{KESESUAIAN AKSESIBILITAS BERDASARKAN PEDOMAN TEKNIS}

Elemen aksesibilitas akan dinilai berdasarkan Peraturan Menteri Pekerjaan Umum No. 30/PRT/M/2006, Peraturan Menteri Pekerjaan Umum dan Perumahan Rakyat No. 14/PRT/M/2017 dan Universal Design Guide Singapore 2016. Pedoman-pedoman yang digunakan akan diolah menjadi butir-butir standar teknis dari fasilitas yang akan dinilai. Pada tiap elemen aksesibilitas memiliki standar teknis untuk dianalisis kesesuaiannya dengan data yang ada di lapangan. Nilai akhir kemudian akan dihitung ke dalam bentuk persentase agar didapat sejauh mana fasilitas tiap segmen telah memenuhi standar aksesibilitas bagi tunanetra berdasarkan pedoman teknis. Elemen aksesibilitas yang dinilai adalah akses, jalur pemandu, jalur pedestrian, area naik turun penumpang, rambu dan markah. Berdasarkan hasil analisis, tiap segmen memiliki peran elemen aksesibilitas yang berbeda. 
Tabel 2. Klasifikasi penilaian

\begin{tabular}{|c|l|}
\hline Persen (\%) & \multicolumn{1}{|c|}{ Ket } \\
\hline $0-33,33$ & Aksesibilitas tidak baik, jauh dari standar. \\
\hline $33,4-66,66$ & $\begin{array}{l}\text { Aksesibilitas cukup baik, memenuhi beberapa } \\
\text { standar. }\end{array}$ \\
\hline $66,67-100$ & $\begin{array}{l}\text { Aksesibilitas baik dan sudah mengikuti } \\
\text { standar-standar yang ada. }\end{array}$ \\
\hline
\end{tabular}

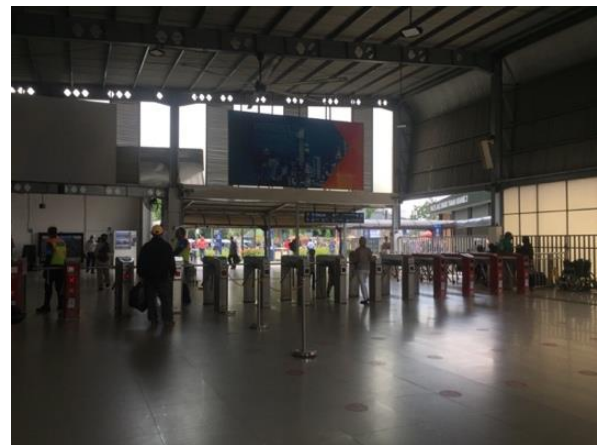

Gambar 10. Segmen 1 (Pintu Utara Stasiun Tanah Abang)

Segmen 1, merupakan pintu utara Stasiun Tanah Abang yang menjadi akses keluar masuk pengunjung yang akan ke Stasiun Tanah Abang. Segmen ini merupakan ruang awal menuju Plaza transit. Pada segmen 1 didapat nilai sebesar 89\%. Elemen aksesibilitas yang telah memenuhi standar dengan baik adalah fasilitas jalur pemandu. Pintu akses berupa turn-sile dengan lebar bukaan $60 \mathrm{~cm}$. Papan informasi pada segmen 1 belum terlalu terlihat karena berupa papan yang digantung ke langit-langit stasiun dan tidak ditemukan ada area informasi lain. Meskipun demikian perletakkan papan informasi tersebut tidak mengganggu lalu-lalang di segmen 1.
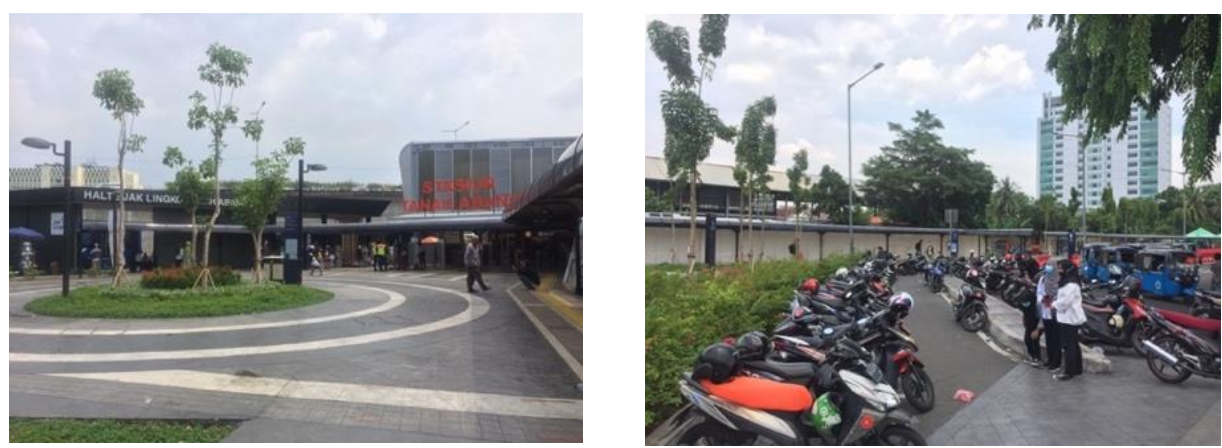

Gambar 11. Segmen 2 (Plaza dan area ojek pengkolan)

Pada Segmen 2, area plaza menjadi ruang pertemuan antar segmen-segmen lain yang ada di plaza transit. Selain itu terdapat pangkalan ojek yang tersedia sebagai pilihan transportasi di segmen 2. Hasil penilaian dengan angka sebesar $79 \%$ yang menunjukkan telah cukup memenuhi standar. Kekurangan pada area ini adalah tidak adanya jalur pemandu menuju pangkalan ojek pengkolan. Keberadaan jalur pemandu hanya terdapat pada sirkulasi yang berbentuk selasar dengan kanopi dimana pengunjung diarahkan menuju segmen selanjutnya. 
Selain itu, rambu dan markah yang ada tidak menggunakan huruf timbul maupun braille serta audio, yang mana informasinya sulit atau tidak bisa diterima oleh penyandang tunanetra.

Segmen 3 merupakan area halte Jaklingko yang menjadi fasilias yang ditempatkan paling dekat dengan pintu utara Stasiun Tanah Abang (segmen 1). Jaklingko sendiri merupakan program yang disediakan untuk memudahkan masyarakat Jakarta dalam menggunakan fasilitas mikrotrans untuk masyarakat tanpa dipungut biaya (gratis). Pada segmen 3 juga terdapat fasilitas penyeberangan yang menjadi akses pejalan kaki dari luar plaza transit.

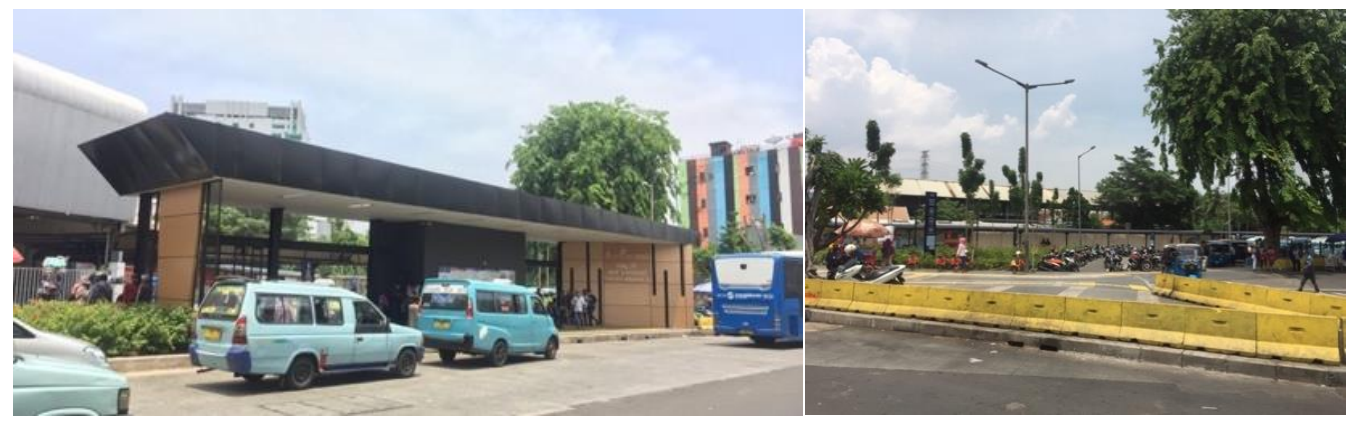

Gambar 12. Segmen 3 (Halte dan area penyeberangan)

Secara keseluruhan elemen aksesibilitas di segmen 3 cenderung baik dan mendapat nilai sebesar $78 \%$. Jalur pedestrian memiliki lebar yang luas sekitar 250-400 cm dan panjang halte sendiri dapat menjangkau dua bus Transjakarta sekaligus. Akses keluar masuk halte terdapat dua buah di tiap sisi sudut halte dan berupa akses tanpa pintu dengan bukaan sekitar $250 \mathrm{~m}$. Terdapat jalur pemandu berupa guiding block dan warning block disepanjang jalur pedestrian yang menjadi area tunggu sebelum menaiki Transjakarta. Kekurangan ada pada rambu lalu lintas sebab tidak terdapat lampu lalu lintas untuk memberikan tanda kepada kendaraan. Hal ini dapat membahayakan tidak hanya bagi tunanetra tetapi juga bagi masyarakat umum.

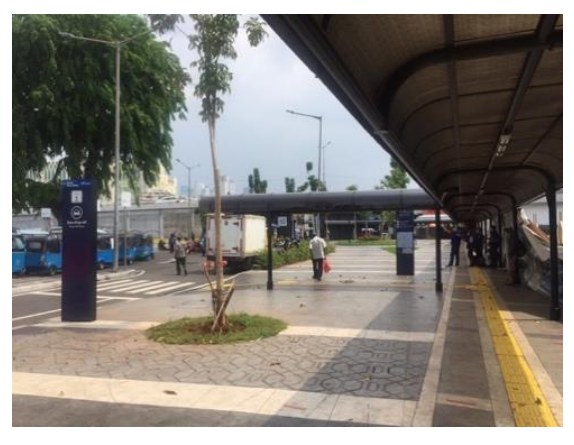

Gambar 13. Segmen 4 (Area Drop-Off)

Segmen 4 merupakan area drop-off yang diperuntukkan bagi kendaraan roda 3 dan 4 . Area ini dilengkapi juga dengan area menyeberang untuk menuju pangkalan mikrolet dan bajaj yang ada di segmen 6 . Segmen 4 mendapat nilai aksesibilitas sebesar $83 \%$. Jalur pemandu yang tersedia cukup baik karena dapat memenuhi standar yang ada. Selain itu tepi pembatas tersedia dalam bentuk pot tanaman yang berapa di pinggir jalur pedestrian sehingga memberikan keamanan dari lau lintas kendaraan. 


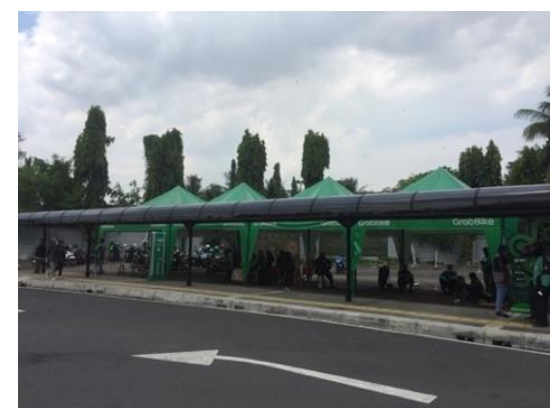

Gambar 14. Segmen 5 (Pangkalan Ojek Online)

Segmen 5 merupakan area pangkalan ojek online yang berada di sisi paling ujung sebelah timur plaza transit. Terdapat tenda-tenda ojek online berwarna hijau berjejer, yang dapat terlihat oleh pengunjung yang keluar dari pintu stasiun di segmen 1. Mendapat nilai sebesar $72 \%$, segmen 5 memiliki jalur pedestrian yang memenuhi standar. Meskipun jarak untuk mencapai segmen 5 merupakan yang paling jauh untuk dicapai, sirkulasi yang disediakan terbilang nyaman akibat adanya selasar dengan kanopi yang menjaga pengunjung dari terik matahari maupun hujan. Papan informasi yang disediakan untuk mengarahkan pengunjung menuju segmen 5 tidak begitu efektif bagi disabilitas tunanetra sebab tidak menggunakan huruf braille maupun informasi dalam bentuk audio. Mudah mengetahui segmen ini melalui visual dari warna hijau terang tenda ojek online yang menonjol.

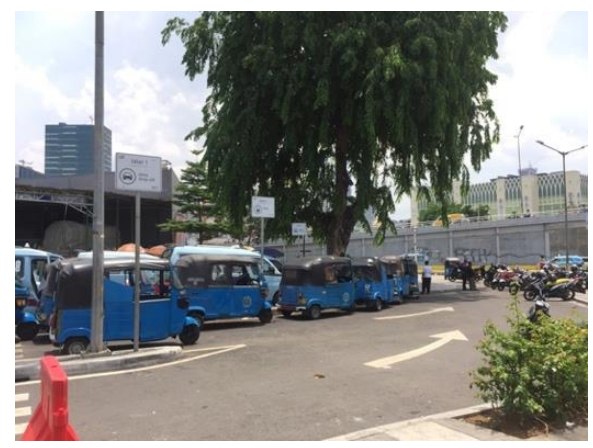

Gambar 15. Segmen 6 (Pangkalan Bajaj \& Mikrolet)

Segmen 6 merupakan area pangkalan bajaj, bemo, dan angkot/ mikrolet. Area ini didominasi dengan sirkulasi kendaraan untuk berhenti sementara dan menjemput/ menurunkan penumpang. Terdapat 3 jalur kendaraan, yaitu jalur untuk naik turun penumpang, jalur untuk bajaj, dan jalur untuk mikrolet. Area ini mendapat nilai sebesar $78 \%$. Jalur pedestrian yang lebih lebar yaitu sekitar $250 \mathrm{~cm}$ bersebelahan dengan jalur mikrolet, terdapat pada sisi terluar plaza transit yang membatasi area plaza transit dengan Jalan Jatibaru Raya. Jalur pedestrian ini memiliki jalur pemandu yang baik, dan pada area menyeberang diberikan pedestrian platform sehingga tidak terjadi perubahan elevasi untuk mencapai jalur pedestrian yang ada di segmen 5 dan segmen 3.

Secara keseluruhan berdasarkan pedoman teknis, elemen aksesibilitas pada plaza transit yang masih kurang sesuai adalah rambu dan markah. Rambu dan markah yang disediakan belum menggunakan tulisan ataupun informasi yang bersifat universal. Selain itu pada beberapa jalur pedestrian yang berbatasan dengan lalu lintas kendaraan, tidak disediakan tepi pengaman. 


\subsection{KESESUAIAN \\ AKSESIBILITAS \\ BERDASARKAN \\ KENYAMANAN TUNANETRA}

Selanjutnya dilakukan analisis berdasarkan kenyamanan yang dirasakan oleh pengunjung tunanetra. Narasumber merupakan tunanetra yang belum familiar dengan Plaza transit, tetapi ketiga narasumber sudah biasa menggunakan Stasiun Tanah Abang. Berikut adalah data tunanetra yang menjadi partisipan dalam penelitian :

Tabel 3. Data Narasumber

\begin{tabular}{|c|c|c|c|c|c|}
\hline Nama & Usia & Pekerjaan & $\begin{array}{l}\text { Tunanetra } \\
\text { Sejak }\end{array}$ & Kondisi Kebutaan & $\begin{array}{c}\text { Pilihan } \\
\text { Transportasi }\end{array}$ \\
\hline N1 & 41 & $\begin{array}{l}\text { Pijat } \\
\text { terapi }\end{array}$ & Lahir & $\begin{array}{l}\text { Total blind } \\
\text { (kebutaan } 90 \% \text {; } \\
\text { menerima cahaya } \\
10 \% \text {; mampu } \\
\text { mendeteksi silau } \\
\text { cahaya) }\end{array}$ & Ojek online \\
\hline $\mathrm{N} 2$ & 38 & $\begin{array}{l}\text { Pedagang } \\
\text { keliling } \\
\& \text { pijat } \\
\text { terapi }\end{array}$ & $\begin{array}{l}\text { Umur } 10 \\
\text { tahun } \\
\text { (akibat step } \\
\& \text { demam } \\
\text { tinggi) }\end{array}$ & $\begin{array}{l}\text { Total blind } \\
\text { (tidak dapat } \\
\text { menerima cahaya } \\
\text { sama sekali) }\end{array}$ & $\begin{array}{l}\text { Ojek } \\
\text { pangkalan/ } \\
\text { ojek } \\
\text { konvensional }\end{array}$ \\
\hline N3 & 43 & $\begin{array}{l}\text { Bidang } \\
\text { jasa }\end{array}$ & Lahir & $\begin{array}{l}\text { Low vision - jarak } \\
\text { jauh } \\
\text { (dapat melihat tetapi } \\
\text { tidak jelas; tidak } \\
\text { dapat melihat huruf; } \\
\text { bisa mendeteksi } \\
\text { benda yang besar) }\end{array}$ & $\begin{array}{l}\text { Busway, Ojek, } \\
\text { Taxi online. } \\
\text { Pilihan } \\
\text { tergantung } \\
\text { kebutuhan. }\end{array}$ \\
\hline
\end{tabular}

4.4 PENGUNJUNG TUNANETRA MENUJU TRANSPORTASI OJEK ONLINE
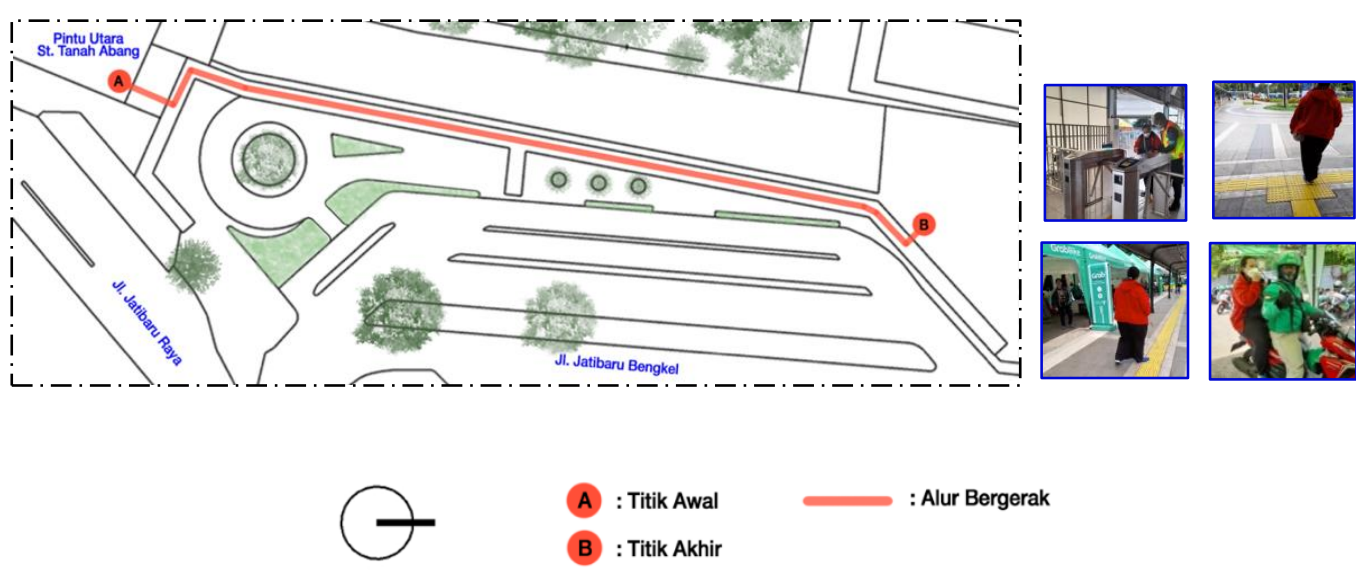

Gambar 16. Alur Gerak Tunanetra Menuju Transportasi Ojek Online

N1 merupakan seorang tunanetra dengan kategori total blind. Beliau tidak dapat melihat apapun dan hanya bisa menerima cahaya sebanyak $10 \%$. Pilihan ojek online menjadi transportasi umum yang biasa digunakannya. Menurut N1 transportasi ojek lebih memudahkan 
untuk bisa sampai di suatu lokasi tanpa perlu berjalan lagi atau berpindah transportasi lagi khususnya pada lokasi dalam jarak dekat. Ojek online memberikan tarif yang murah bagi N1 dan beliau terbiasa menggunakan handphone android yang menyediakan fasilitas untuk mengubah kalimat atau gambar yang disentuh menjadi suara.

Dalam mengakses pintu turn-sile di segmen 1, beliau merasa kesulitan untuk menemukan area tap kartu pada mesin tersebut. N1 kemudian diberi bantuan oleh petugas stasiun. Setelah melalui segmen 1, dengan mengikuti jalur pemandu untuk keluar dari area stasiun, N1 menuju ke ruang yang lebih terbuka. N1 mendeteksi keberadaannya sudah ada di luar stasiun dengan merasakan hembusan angin yang cenderung lebih besar. Untuk mengetahui arah yang perlu dituju, saat N1 merasa ada orang didekatnya ia akan langsung bertanya. Meskipun mendapatkan bantuan dari hasil bertanya, N1 masih kesulitan untuk mengartikan arahan yang bersifat non-verbal seperti tunjukan atau gerakan tangan lainnya. Setelah bertanya, N1 menangkap sebuah informasi yang mengarahkan N1 untuk bergerak "lurus saja hingga ke ujung" yang diberikan salah satu pengunjung plaza transit. Ketika sampai di segmen 5, N1 mendeteksi bahwa ia sudah sampai di pangkalan ojek dengan merasakan adanya keramaian orang. N1 tidak mengandalkan jalur pemandu dalam hal ini sebab jalur pemandu di segmen 5 tidak terdapat warning block dan hanya berupa guiding block yang mengarahkan penggunanya keluar dari area plaza transit tersebut. Saat di pangkalan ojek online, N1 diberikan area untuk duduk yang disediakan oleh pihak ojek tersebut selagi menunggu dan memesan melalui aplikasi. N1 diarahkan menuju ojek yang telah datang menjemput dengan didampingi tukang ojek lainnya. N1 tidak dapat menemukan ojek pesanannya tanpa diarahkan karena pada area pangkalan sudah tidak ada jalur pemandu. Area khusus untuk naik turun penumpang pada segmen ini tergabung dengan area parkir ojek online.

Menurut N1, selama perjalanan menuju transportasi ojek online di plaza transit terasa mudah dan nyaman. Pelayanan dan bantuan yang didapat N1 sewaktu berada di plaza transit dinilai oleh N1 sudah sangat baik dan memberikan kemudahan dalam mencapai lokasi tujuan. Di Plaza Transit Stasiun Tanah Abang kenyamanan dirasakan N1 karena tidak ada pedagang kaki lima (PKL) yang dulu sering memenuhi jalur pedestrian dan menyebabkan tongkat pemandu tersangkut. Jalur pedestrian yang terasa luas membuat pergerakan menjadi lebih bebas dan terhindar dari tabrakan dengan lalu lalang pengunjung lain khususnya disepanjang jalur pemandu. Kanopi yang ada disepanjang jalur pemandu memberikan peneduhan dari panasnya terik matahari serta cukup untuk laju dua arah tanpa khawatir tongkat pemandu akan mengenai pengunjung lain. Pergerakan tunanetra cenderung lambat dan terkadang menyebabkan N1 tersenggol ataupun tertabrak oleh sesuatu.

\subsection{PENGUNJUNG TUNANETRA MENUJU TRANSPORTASI OJEK PENGKOLAN}

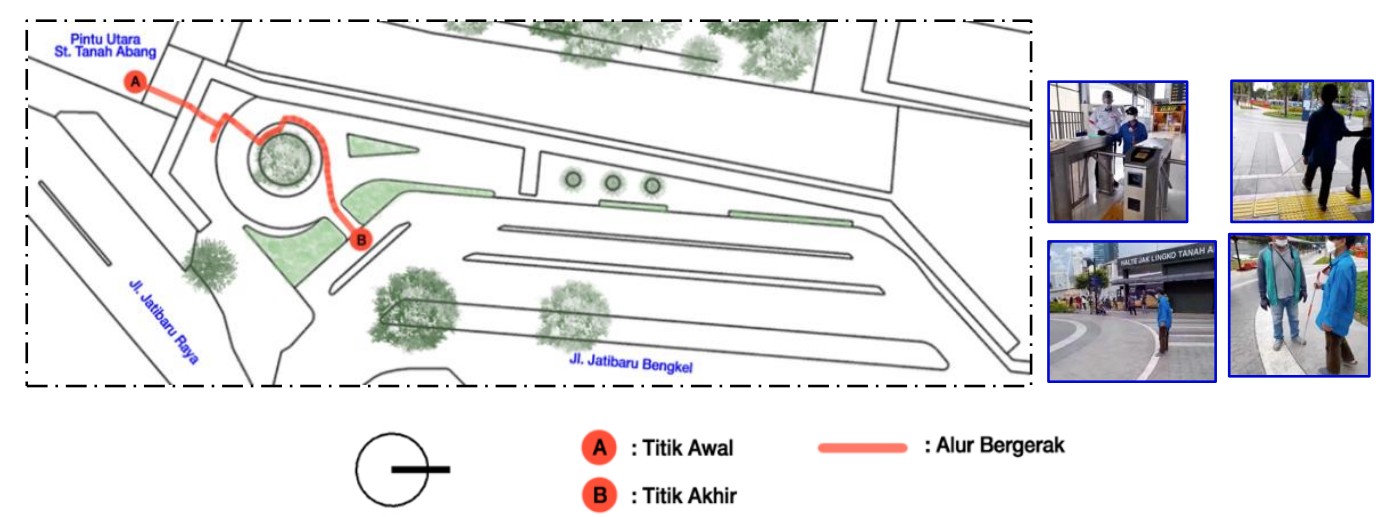

Gambar 17. Alur Gerak Tunanetra Menuju Transportasi Ojek Pengkolan 
N2 merupakan seorang tunanetra total blind sejak berusia 10 tahun, yang tidak dapat menerima cahaya sama sekali. Kondisi penglihatan yang dirasakannya adalah gelap total. N2 tidak terbiasa menggunakan hanphone dan memilih ojek pengkolan sebagai transportasi yang biasa digunakannya.

Akses pintu turn sile tidak menyulitkan untuk dilalui oleh N2. Setelah melalui akses, N2 mengikuti jalur pemandu dengan mengetukkan tongkat ke ubin. Saat sampai di area yang terbuka, N2 berhenti dan bertanya kepada orang sekitar mengenai lokasi ojek pengkolan. Kemudian N2 diarahkan berjalan keluar jalur pemandu hingga sampai ke segmen 2 yaitu area plaza. Jalur pedestrian di plaza tidak memiliki jalur pemandu sehingga N2 sempat berdiam dan bergerak tanpa arah. N2 mencari tepian trotoar dari jalur pedestrian sebagai alternatif dari jalur pemandu. Tetapi posisi N2 masih jauh dari trotoar jalan dan N2 menuju area berumput yang ada di tengah plaza. Sebelum sempat mengitasi sisi pinggir area taman, N2 diberikan bantuan oleh ojek pengkolan yang berdiri dan mencari pelanggan di sekitar plaza. N2 kemudian diantar oleh tukang ojek menuju pangkalan ojek.

Bagi N2 meskipun terdapat kendala, area plaza transit dirasa aman untuk melakukan gerakan. Kesulitan yang muncul dapat diatasi dengan respon yang sigap dari orang sekitar terhadap N2. Fasilitas informasi dirasa masih sangat kurang untuk N2 mencari arah dan mengidentifikasi area-area yang disediakan di plaza transit. Menurut N2 kelengkapan jalur pemandu menjadi elemen aksesibilitas yang sangat diandalkan olehnya jika berada di suatu tempat. Tidak adanya jalur pemandu sangat menyulitkan bagi N2 untuk mengenali ataupun memenuhi kebutuhan aktivitasnya pada suatu area.

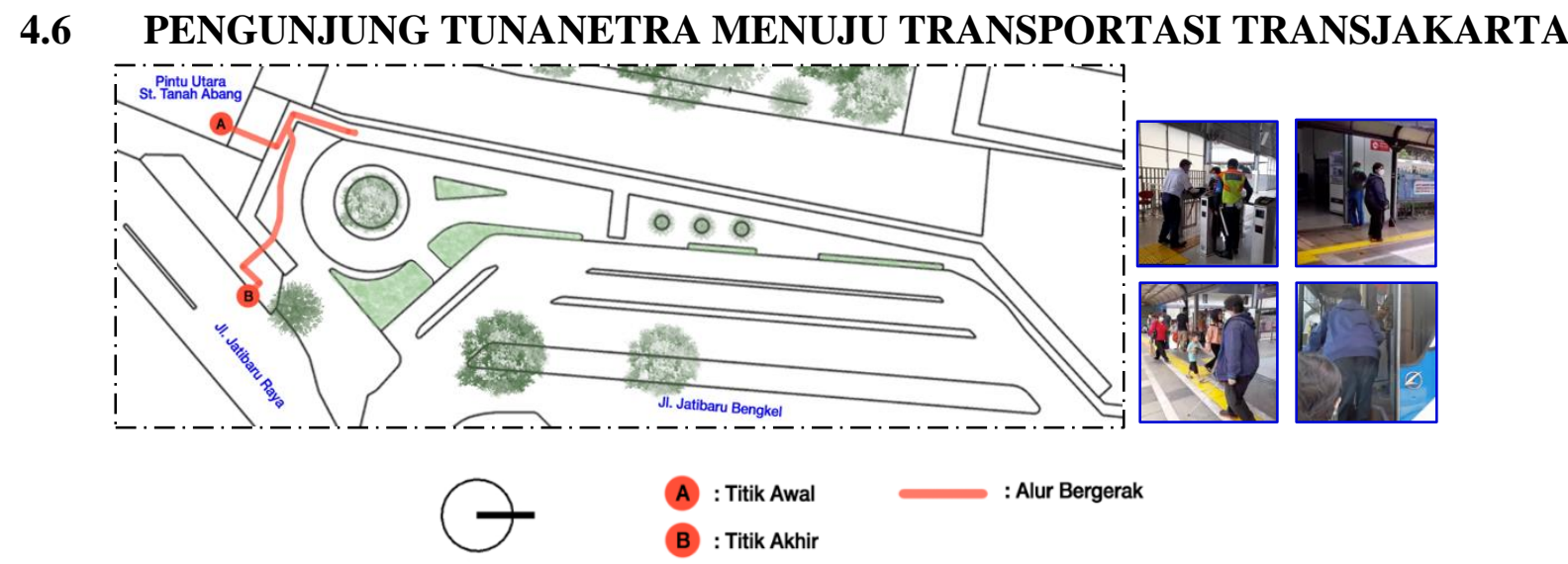

Gambar 18. Alur Gerak Tunanetra Menuju Transportasi Ojek Pengkolan

N3 merupakan tunanetra dengan kategori low vision jarak jauh. Kemampuan penglihatannya masih ada tetapi tidak jelas, tidak dapat membaca dan melihat wujud secara jelas tetapi bisa mendeteksi lokasi benda atau orang disekitarnya. Dalam menggunakan akses pintu turn sile N3 tidak kesulitan. Setelahnya N3 mengikuti jalur pemandu kearah segmen 4 yaitu area drop off. Lokasi yang dituju N3 pada awalnya salah arah sebab Transjakarta memiliki halte tersendiri. N3 diberikan bantuan arah oleh orang sekitar yang menunjukkan lokasi halte Jaklingko. Karena masih dapat melihat, N3 dapat menerima arahan yang ditunjuk oleh orang sekitar. Kemudian setelah melihat lokasi halte Jaklingko N3 berbalik arah dan menuju lokasi tanpa melalui jalur pemandu. Saat tiba di halte, N3 menunggu di area yang terdapat warning block, dan menaiki Transjakarta dengan dibantu petugas. Menurut N3 Plaza transit sudah 
cukup nyaman, tetapi beliau kesulitan memiliki ruang gerak saat ada di area yang terdapat PKL. Keramaian dari PKL menghalangi kebebasan bergerak.

Menurut N3 plaza transit sudah cukup nyaman dan tidak terganggu oleh halangan apapun selama bergerak. Meskipun masih bisa melihat, N3 tidak menyadari keberadaan halte yang sangat dekat dengan akses pintu utara Stasiun Tanah Abang. Hal ini disebabkan N3 tidak mampu membaca tulisan "Janglingko" yang dapat dilihat mudah oleh orang tanpa gangguan penglihatan dari arah plaza. (segmen 2).

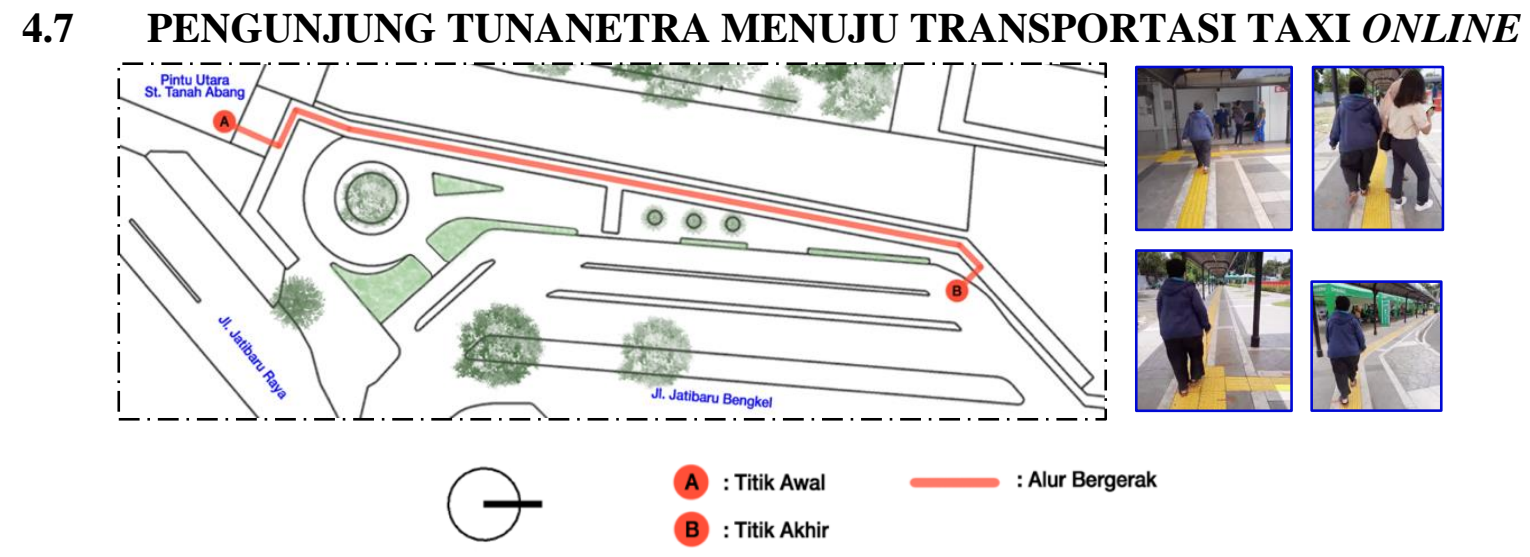

Gambar 19. Alur Gerak Tunanetra Menuju Transportasi Ojek Pengkolan

N3 juga mencoba untuk menggunakan transportasi taxi online. Setelah melalui pintu turn sile, N3 mengikuti jalur pemandu menuju segmen 4 yang merupakan area drop off. Sesampainya di segmen 4, N3 tetap bergerak lurus menuju segmen 5 karena melihat adanya tenda-tenda ojek online. Dalam hal ini N3 mengalami kekeliruan dalam mengetahui area naik turun untuk kendaraan roda 4 yang seharusnya berada di segmen 4 . Hal ini dimungkinkan karena N3 memiliki pemahaman bahwa fasilitas transportasi taxi online memiliki area yang sama dengan ojek online karena kedua transportasi tersebut berasal dari perusahaan jasa yang sama yaitu "gojek" atau "grab". Informasi lain yang diterima dari supir taxi online sendiri, mereka terkadang merasa takut untuk mengangkut penumpang di area drop off yang telah disediakan. Area drop off yang ada bersebelahan dengan pangkalan mikrolet dan bajaj yang menyebabkan munculnya peraturan tersendiri yang dibuat oleh orang sekitar kepada jasa taxi online untuk tidak mengangkut penumpang di area drop off tersebut.

Dalam menuju taxi online N3 merasa cukup nyaman dan tidak merasa ada halangan dalam mencapai taxi online. Arah menuju segmen 5 yang sebenarnya merupakan lokasi pangkalan ojek online, bagi N3 cukup nyaman dan aman. Meskipun tidak menggunakan area drop off di segmen 4, sirkulasi kendaraan bagi transportasi umum pada segmen 5 terhubung dengan segmen 4 . Kondisi ini memudahkan bagi taxi online untuk menemukan N3 sehingga N3 tidak perlu kesulitan menemukan taxi yang dipesan.

\subsection{SINTESIS}

Hasil penilaian berdasarkan pedoman teknis dikomparasikan dengan pengalaman narasumber tunanetra. Tabel memperlihatkan persentase nilai aksesibilitas dari tiap segmentasi di plaza transit. Tiap segmen tersebut yang telah digunakan dan dirasakan langsung oleh narasumber tunanetra, diberi tanda yang menunjukkan mudah atau sulitnya segmen tersebut bagi kebutuhan orientasi dan mobilitas tunanetra. Elemen aksesibilitas yang menjadi faktor 
yang mempengaruhi kemudahan serta kesulitan tunanetra dalam navigasi, dibedakan ke dalam kategori kendala dan potensi.

Tabel 4. Sintesis

\begin{tabular}{|c|c|c|c|c|c|c|c|}
\hline \multirow{2}{*}{ Segmen } & \multirow{2}{*}{$\begin{array}{c}\text { Nilai } \\
\text { Berdasarkan } \\
\text { Pedoman } \\
\text { Teknis }\end{array}$} & \multicolumn{2}{|c|}{$\begin{array}{c}\mathrm{N}-1 \\
(\text { total blind })\end{array}$} & \multicolumn{2}{|c|}{$\begin{array}{c}\mathrm{N}-2 \\
\text { (total blind) }\end{array}$} & \multicolumn{2}{|c|}{$\begin{array}{c}\mathrm{N}-3 \\
\text { (low vision) }\end{array}$} \\
\hline & & $\mathbf{O}$ & $\mathbf{M}$ & $\mathbf{O}$ & $\mathbf{M}$ & O & $\mathbf{M}$ \\
\hline Z-1 & $89 \%$ & $X$ & V & $\mathrm{V}$ & $\mathrm{V}$ & $X$ & $\mathrm{~V}$ \\
\hline Z-2 & $79 \%$ & - & - & $X$ & $\mathrm{~V}$ & $\mathrm{~V}$ & $\mathrm{~V}$ \\
\hline Z-3 & $78 \%$ & - & - & - & - & $\mathrm{V}$ & $\mathrm{V}$ \\
\hline Z-4 & $83 \%$ & $\mathrm{~V}$ & $\mathrm{~V}$ & - & - & $X$ & $\mathrm{~V}$ \\
\hline Z-5 & $72 \%$ & $\mathrm{~V}$ & $\mathrm{~V}$ & - & $\mathrm{V}$ & $\mathrm{V}$ & $\mathrm{V}$ \\
\hline Z-6 & $78 \%$ & - & - & - & - & - & - \\
\hline
\end{tabular}

Ket: $(\mathrm{O})=$ Orientasi, $(\mathrm{M})=$ Mobilitas, $(\mathrm{V})=$ Mudah, $(\mathrm{X})=$ Sulit, $(-)=$ Tidak mengalami segmen tersebut

Kendala :

- Rambu dan markah yang tidak dapat ditangkap infomasinya oleh tunanetra.

- Tepi pengaman yang tidak ada dan dapat memudahkan akses bagi PKL.

Potensi :

- Jalur pemandu sudah cukup lengkap dan menggunakan susunan guiding block dan warning block yang sesuai standar.

- Jalur pedestrian luas tanpa lubang dan gundukan.

- Selasar untuk area berjalan dengan penutup atap sehingga menjaga penggunanya dari cuaca.

- Tidak adanya perbedaan elevasi memudahkan dan mempercepat pergerakan tunanetra.

Melalui tabel dapat terlihat perbandingan antara kualitas aksesibilitas berdasarkan pedoman teknis dengan pengalaman kemudahan yang dirasakan tunanetra secara langsung. Ditemukan adanya kesulitan orientasi pada Z-1 (segmen 1), Z-2 (segmen 2) dan Z-4 (segmen 4) meskipun segmen tersebut memiliki persentase nilai yang tinggi. Sedangkan pada Z-3 (segmen 3) dan Z-5 (segmen 5), narasumber tunanetra merasa cukup mudah baik dalam orientasi maupun mobilitas.

Pada segmen tertentu, kelengkapan elemen aksesibilitas menjadi lebih penting ketersediaannya tergantung pada aktivitas yang terjadi pada segmen tersebut. Seperti yang terjadi pada Z-1 sebagai awal dari kelanjutan perjalanan, pengunjung stasiun membutuhkan sumber informasi lebih lengkap dan mencakupi seluruh penggunanya. Hal ini yang menjadi salah satu faktor ditemukannya perbedaan antara nilai aksesibilitas dengan pengalaman tunanetra yang ada pada tabel 4. Melalui kendala dan potensi yang telah dijabarkan menunjukkan bahwa plaza transit telah berupaya menyediakan fasilitas publik untuk kenyamanan aksesibilitas penggunanya. Ragam kebutuhan dari pengguna yang berbeda menyebabkan kekurangan fasilitas dapat menjadi kendala bagi mereka yang membutuhkan dan dalam hal ini yang dimaksud adalah pengguna tunanetra. 


\section{KESIMPULAN}

Melalui hasil analisis yang ada, ingin diketahui sejauh mana elemen aksesibilitas di Plaza transit telah mengkomodasi pengunjung tunanetra. Dalam penilaian berdasarkan pedoman teknis, Plaza transit memiliki range nilai dari $72-89 \%$ yang berarti Plaza transit tersebut dianggap sudah cukup baik dalam mematuhi standar secara universal. Namun demikian, masih ada beberapa hal yang perlu dilengkapi lagi berdasarkan penglaman tunanetra.

Bagi pengunjung tunanetra, Plaza transit sudah cukup aman dan nyaman dalam bergerak. Meskipun demikian, kesulitan dirasakan saat harus menentukan arah secara mandiri. Tunanetra belum dapat mencari arah dalam keadaan yang tidak familiar dengan Plaza transit tersebut. Untuk mengatasi hal ini, tunanetra mengandalkan bantuan orang lain dan juga pelayanan yang bisa didapat dari petugas stasiun atau fasilitas terkait.

Untuk menjaga dan mengembangkan potensi aksesibilitas di plaza transit pemanfaatan fasilitas yang tepat guna akan meminimalisir hambatan bagi tunanetra juga pengguna ruang lainnya. Penelitian yang dilakukan memberikan gambaran bahwa aksesibilitas ruang terbuka memiliki manfaat yang penting bagi penggunanya. Dalam konteks penelitian ini, tunanetra memerlukan aksesibilitas agar bisa lebih beraktivitas secara mandiri. Kualitas aksesibilitas perlu didukung dengan kerjasama dari masyarakat sebagai pengguna ruang dan peraturan yang efektif diterapkan, untuk bisa membangun lingkungan yang adil dan merata bagi penggunanya.

\section{DAFTAR PUSTAKA}

AINI, Q., MARLINA, H., NIKMATULLAH, A. (2019). Evaluation of Accesibility for People with Disability in Public Open Space. Banda Aceh: Universitas Muhammadiyah Aceh.

ARIF, H. (2008). Kajian Aksesibilitas Difabel Pada Ruang Publik Kota Studi Kasus: Lapangan Merdeka. USU Repository.

ANDRIANSYAH. (2015). Manajemen Transportasi dalam Kajian Teori. Indonesia: Universitas Prof. Dr. Moestopo Beragama.

BUILDING AND CONSTRUCTION AUTHORITY. (2016). Universal Design Guide for Public Space. Singapura: BCA.

CHAER, A. (2017). Tenabang Tempo Doeloe. Depok: Masup Jakarta.

COLENBRANDER A., LIEBERMANN, M.F., \& SCHAINHOLZ, D.C. (1992). Preliminary Implementation of the Functional Vision Score on the Humphrey Field Analyzer. Kyoto: International Perimetric Society.

GEHL, J. (2011). Life Between Buildings: Using Public Space. Washington DC : Island Press.

GENSE, J. \& MARILYN, G. (Eds.). (2004).The Importance of Orientation and Mobility Skills for Students Who Are Deaf-Blind. US : Perkins School for the Blind Teaching Research.

HALLAHAN, D., JAMES, K. \& PAIGE, P. (2009). Exceptional Learners: An Introduction to Special Education (12th ed.). Boston: Pearson.

JERNIGAN, K. (Ed). (2005). A Definition of Blindness. Diakses tanggal 28 September 2020,dari https://bit.ly/3jt8Dl1.

LUBIS, H.A. (2008). Kajian Aksesibilitas Difabel pada Ruang Publik Kota Studi Kasus: Lapangan Merdeka. Medan: Sekolah Pascasarjana Universitas Sumatera Utara.

MACE, RONALD. (1985). Accessible Environments: Toward Universal Design. USA: The Center for Universal Design North Carolina State University

PERATURAN MENTERI PEKERJAAN UMUM DAN PERUMAHAN RAKYAT RI Nomor 14 Tahun 2017 Persyaratan Kemudahan Bangunan Gedung.

PERATURAN MENTERI PEKERJAAN UMUM RI Nomor 30 Tahun 2006 Pedoman Teknis Aksesibilitas dan Fasilitas Bangunan Gedung dan Lingkungan. 
STEINFELD, E. \& JORDANA, M. 2012. Universal Design: Creating Inclusive Environments. New Jersey: Wiley \& Son

VERMEERSCH, P. W., STRICKFADEN, M., HERSSENS, J., \& HEYLIGHEN, A. (2009). Architects and Visually Impaired People: Analyzing Two Ways of Talking. USA: Standford University.

WEBSTER, A. \& JOAO, R. (1998). Children with visual impairment: Social interaction, language and learning. New York: Routledge .

WAHYUNI, S., MURTI, B. AND JOEBAGIO, H.(2016). Public Transport Accessibility for People with Disabilities. Surakarta: Sebelas Maret University.

WOOLLEY, H. (2003). Urban Open Space. London : Spon Press.

YOHANNES, A. (2001). Kajian Orientasi dan Mobilitas Kaum Tunanetra Terhadap Lingkungan Dengan Objek Studi PSBN Wyata Guna. Bandung: Universitas Katolik Parahyangan. 